
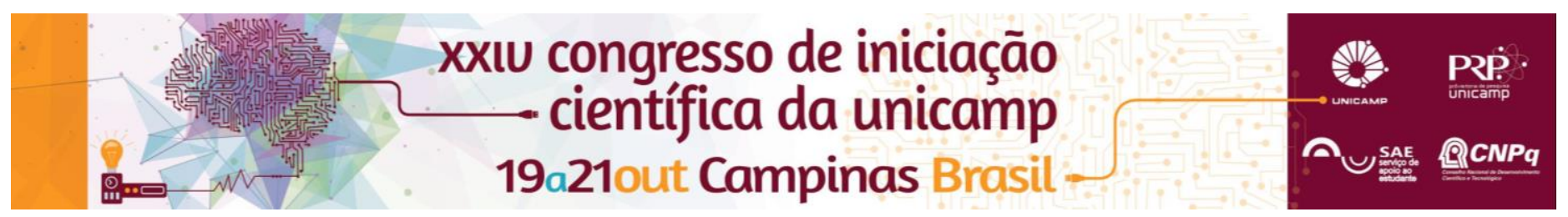

\title{
Organização da coleção didática de Zoologia de Invertebrados da UNICAMP
}

\author{
Vinícius F. Bissoli, Marília Baltazar, Ana Laura Leme, Renata Alitto, Fosca P. P. Leite, Gustavo Q. Romero.
}

\section{Resumo}

As coleções zoológicas são recursos didáticos fundamentais utilizados em aulas práticas. A fim de garantir melhores condições de ensino e aprendizado, portanto, é imprescindível a organização dos espécimes. Neste trabalho, realizamos a curadoria da coleção didática em moldes similares aos de uma coleção científica. Trocamos a vidraria, repomos o álcool, organizamos os armários e elaboramos etiquetas para cada amostra. Contabilizamos 45 grupos de invertebrados e mais de 1000 lotes com espécimes.

Palavras-chave: coleções zoológicas, aulas práticas, ensino de ciências.

\section{Introdução}

Coleções zoológicas são fontes importantes de informações para o conhecimento da biodiversidade. Esta notabilidade é ainda maior quando são usadas como recursos didáticos no ensino de Ciências Biológicas ${ }^{1}$. Para que o aprendizado seja mais eficiente é de fundamental importância que as coleções estejam organizadas, armazenadas e identificadas corretamente. A organização da coleção didática traz benefícios tanto para os alunos, quanto para os professores e monitores. Diante deste cenário, nosso objetivo foi organizar a Coleção Didática Zoológica de Invertebrados referente às disciplinas BZ380/382 do Departamento de Biologia Animal da UNICAMP.

\section{Metodologia}

Realizamos a curadoria da coleção didática de Invertebrados da UNICAMP de março a julho de 2016. Completamos e/ou repomos o álcool das amostras e realizamos a troca da vidraria. Descartamos os potes de plástico, pois estes não vedam corretamente, permitindo que o álcool evapore e aumentando o risco de perda dos espécimes. Posteriormente, fizemos uma etiqueta para cada amostra com dados de: nível taxonômico (filo, classe e/ou ordem) e, quando de conhecimento geral, o nome popular. Por fim, esvaziamos dois armários de aço, que foram disponibilizados para UNICAMP utilizar em outros departamentos e planejamos uma nova disposição dos armários da sala de armazenamento das coleções didáticas.

\section{Resultados e Discussão}

Contabilizamos 45 coleções didáticas pertencentes à diversos grupos do Reino Animal estudados nas disciplinas BZ380/382. Organizamos a coleção dos seguintes táxons de invertebrados: Onychophora, Tardigrada, Chelicerata, Myriapoda, Hexapoda, Crustacea, Echinodermata, Bryozoa, Brachiopoda, Hemichordata e Tunicata. As coleções totalizaram 1004 lotes, sendo que os Crustacea e os Hexapoda foram os mais representativos (Figura 1). Também montamos uma pequena coleção de amostras de plâncton e de organismos meiofaunais como Gastrotricha e Rotifera. As coleções foram armazenadas em via úmida (álcool $70 \%$ ), via seca ou lâminas. Usamos 84 litros de álcool no total, que foram diluídos até a concentração de $70 \%$ e trocamos cerca de 400 vidros. Separamos os melhores espécimes para as aulas práticas, incluindo exemplares de machos e fêmeas de aranhas e caranguejos. A organização do material didático facilita a busca dos materiais e otimiza a preparação das aulas práticas. A nova disposição dos armários promoveu uma melhor circulação e aproveitamento do espaço.

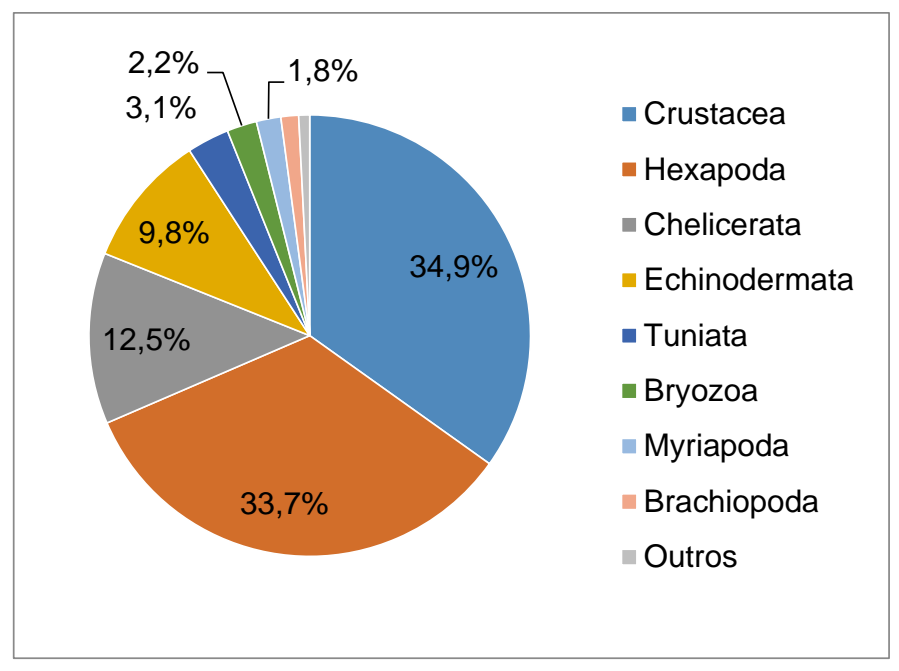

Figura 1: Representatividade dos grupos de animais vistos nas disciplinas BZ380/382 em percentual de lotes depositados na coleção didática de Invertebrados da UNICAMP.

\section{Conclusões}

Com este trabalho concluímos que é inegável a importância de manter as coleções didáticas organizadas, visto que os materiais zoológicos constituem uma ferramenta única para se por em prática conceitos teóricos. Assim, o correto armazenamento da coleção didática proporciona melhores condições de ensino e formação dos futuros biólogos da UNICAMP.

\section{Agradecimentos}

Agradecemos ao Museu de Zoologia da Unicamp pela doação de vidros e à UNICAMP pelas bolsas PAD, PED e SAE dos monitores da disciplina BZ380/382.

${ }^{1}$ Azevedo, H.J.C.C. et al. 2012. O uso de coleções zoológicas como ferramenta didática no ensino superior: um relato de caso. Revista Práxis, IV nº 7. 